University of Nebraska - Lincoln

DigitalCommons@University of Nebraska - Lincoln

November 1984

\title{
Crop Residue Removal and Soil Productivity with No-Till Corn, Sorghum, and Soybean
}

J. W. Doran

USDA-ARS

Wallace Wilhelm

University of Nebraska-Lincoln, wwilhelm1@unl.edu

J. F. Power

USDA-ARS

Follow this and additional works at: https://digitalcommons.unl.edu/usdaarsfacpub

Part of the Agricultural Science Commons

Doran, J. W.; Wilhelm, Wallace; and Power, J. F., "Crop Residue Removal and Soil Productivity with No-Till Corn, Sorghum, and Soybean" (1984). Publications from USDA-ARS / UNL Faculty. 116.

https://digitalcommons.unl.edu/usdaarsfacpub/116

This Article is brought to you for free and open access by the U.S. Department of Agriculture: Agricultural Research Service, Lincoln, Nebraska at DigitalCommons@University of Nebraska - Lincoln. It has been accepted for inclusion in Publications from USDA-ARS / UNL Faculty by an authorized administrator of DigitalCommons@University of Nebraska - Lincoln. 


\title{
Crop Residue Removal and Soil Productivity with No-Till Corn, Sorghum, and Soybean'
}

\author{
J. W. Doran, W. W. Wilhelm, AND J. F. POWER ${ }^{2}$
}

\begin{abstract}
Crop residues have been considered during the past decade as alternate energy sources to supplement dwindling fossil fuel sources and enhance energy independence in the United States. Agricultural scientists have demonstrated the importance of crop residues in reducing soil erosion, enhancing the soil physical environment for plant growth, and as a reserve for major crop nutrients. In eastern $\mathrm{Ne}-$ braska, we evaluated the effects of various amounts of surface crop residues (aboveground dry matter remaining after harvest) on dryland production of no-till corn (Zea mays L.), sorghum [Sorghum bicolor (L.) Moench], and soybean [Glycine max (L.) Merrill] over a 3-yr period. Where crop residues were completely removed after harvest, average grain and residue yields of corn and soybean were 22 and $24 \%$ lower, respectively, than where residues were not removed. Removal of $50 \%$ or addition of $50 \%(150 \%)$ surface crop residues had little or no effect on crop yields compared to no removal (100\%).

Sorghum yields were unaffected by residue removal, but stands were significantly less at the $150 \%$ residue rate. Yield reductions for corn and soybean resulted primarily from decreased soil water storage and excessive surface soil temperatures where residues were completely removed. Sorghum tolerated conditions of temperature and water stress better than other crops. Removal of surface crop residues can seriously reduce corn and soybean yields in climates where stressful conditions occur during the growing season. Considerations for using crop residues as alternate energy sources should include these potential reductions in grain and residue yields, as well as increased nutrient removal and greater potential for soil erosion.
\end{abstract}

Additional Index Words: biomass energy, residue management, conservation tillage, crop rotations, plant stress.

Doran, J. W., W. W. Wilhelm, and J. F. Power. 1984. Crop residue removal and soil productivity with no-till corn, sorghum, and soybean. Soil Sci. Soc. Am. J. 48:640-645.

\footnotetext{
${ }^{1}$ Contribution from the Agricultural Research Service, USDA, in cooperation with the Nebr. Agric. Exp. Stn., Univ. of NebraskaLincoln. Published as Paper no. 7262 Journal Series, Nebr. Agric. Exp. Stn. Received 12 Aug. 1983. Approved 9 Nov. 1983.

${ }^{2}$ Soil Scientist, Plant Physiologist, and Research Leader (Soil Scientist), ARS, USDA, Univ. of Nebraska-Lincoln, Lincoln, NE 68583.
}

$A$ LMOST 400 MiLlion METRIC TONS ( $\mathrm{Tg}$ ) of dry crop $A$ residues (aboveground dry matter remaining after grain harvest) are produced annually in the United States by the 15 major crop plants. Seventy-five percent of this amount is produced by the three major crops-corn (Zea mays L.), soybean [Glycine max (L.) Merrill], and wheat (Triticum aestivum L.) (USDA, 1978). At present, nearly $70 \%$ of the total crop residues produced is returned to the land, $26 \%$ is fed to livestock, and the remainder is either used as fuel, sold for other purposes, or wasted. Recently, crop residues have been considered as an alternate source of energy to supplement the dwindling supplies of oil and natural gas in the U.S. (Burwell, 1978). Considering collection efficiencies and the need for maintaining soil productivity, only $20 \%$ of the crop residues presently returned to the soil would be available for use as alternate energy sources-enough to meet 1 to $1.5 \%$ of the U.S. energy needs (Larson et al., 1978; Office of Technology Assessment, 1980).

Crop residues play an important role in maintaining soil productivity and should not be considered waste products totally available for use as alternate energy sources. They protect soil from wind and water erosion, are a large reservoir of plant nutrients, and maintain the physical environment of soil as a desirable medium for plant growth. The quantity of crop residues needed to maintain soil productivity varies with climate, topography, soil, and management systems. Linstrom et al. (1981) calculated that $79 \mathrm{Tg}$ of crop residues ( $58 \%$ of the total produced) could be removed from the land in the 10 major corn-producing states without exceeding allowable soil erosion loss for continued long-term soil productivity. In the Great Plains, only $21 \%$ of the total crop residues could be removed without seriously increasing soil erosion potential (Linstrom et al., 1979). The specific quantities of residue that could be safely removed varied with tillagemanagement practices, with greater amounts being available with no tillage than with conventional tillage. 
Residues also contain valuable crop nutrients that represent 40,10 , and $80 \%$ of the $\mathrm{N}, \mathrm{P}$, and $\mathrm{K}$, respectively, of the fertilizer applied to all crops in the U.S. (USDA, 1978). In the Corn Belt and Plains States, the residue equivalency for $\mathrm{N}$ represents $60 \%$ of the fertilizer usage for this area (Larson et al., 1978).

Returning crop residues to soil favorably influences organic-matter levels, structure, storage and movement of water and air, and other determinants of soil productivity (Parr and Papendick, 1978; Power and Legg, 1978; USDA, 1978). Where crop residues are continuously removed, soil organic-matter levels decrease until a new steady state is reached. Organicmatter levels of conventionally tilled soil cropped to corn in Indiana and Iowa decreased 10 to $13 \%$ within 10 to 12 years when crop residues were removed (Barber, 1979; Larson et al., 1972). Larson et al. (1972) demonstrated that, with plowing in Iowa, 4.5 metric tons/ha $\left(\mathrm{Mg} \mathrm{ha}^{-1}\right)$ of corn residues were needed to maintain soil organic-matter levels. The rate of decline of soil organic-matter levels, however, is greatly reduced when conservation-tillage practices are used (Doran and Power, 1983).

Maintaining crop residues on soil surfaces also increases infiltration rates (Mannering and Meyer, 1963), reduces surface runoff (Greenland, 1975), reduces evaporation rates (Bond and Willis, 1969), and increases entrapment of snow (Willis et al., 1961)-all mechanisms by which water storage and crop growth are enhanced. Surface crop residues also result in lower average soil temperatures during the growing season and reduced diurnal temperature fluctuations (Larson et al., 1978). In northern regions, reduced soil temperatures may decrease early season crop growth, but in more temperate and tropical regions, surface crop residues may enhance seed germination and growth by reducing the adverse effects of high daytime air and soil temperatures (Greenland, 1975). The objective of this research study was to determine the short-term effects of crop-residue management on crop growth and soil productivity in a subhumid climatic zone.

\section{MATERIALS AND METHODS}

The study was conducted from 1978 through 1980 on a Crete-Butler silty clay loam (fine, montmorillonitic, mesic Pachic Argiustolls-Abruptic Argiaquolls) in eastern $\mathrm{Ne}-$ braska. This area is transitional between the Corn Belt and central Great Plains. Climate is typically continental, with $76 \%$ of the total $(717 \mathrm{~mm}$ ) annual precipitation falling between April and September. Rainfall distribution throughout the growing season is highly variable. Periods of plant stress resulting from limited rainfall, air temperatures above $37^{\circ} \mathrm{C}$, or hot, dry winds are fairly common. The Crete-Butler soil at the experimental site developed from loessal materials and contains 14 to $16 \%$ sand, 49 to $53 \%$ silt, and 32 to $35 \%$ clay in the surface $300 \mathrm{~mm}$. Volumetric water contents at -0.033 and $-1.500 \mathrm{MPa}$ matric potential (field capacity and permanent wilting point) average 42.3 and $21.2 \%$, respectively. The experimental site was nearly level (0-2\% slope), largely eliminating effects between treatments resulting from differences in soil erosion rates.

Residue treatments within each crop were arranged in a randomized, complete block design with four replications. Plots were 12.2 by $12.2 \mathrm{~m}$. The rotation sequence of corn, sorghum [Sorghum bicolor (L.) Moench], and soybean was not replicated, but the experiment was repeated for each crop on three adjacent fields. A rotation of corn, sorghum, and soybean was used because these are major residueproducing crops; also, this rotation enabled us to evaluate effects of these crop residues on soil productivity changes with minimum complication from disease, weed, and insect problems, which could have been accentuated by monoculture. To initiate the experiment in 1978, wheat straw was spread on the surface of respective treatments during the fall of 1977 at rates of $0,1.5,3.0$, and $4.5 \mathrm{Mg} \mathrm{ha}^{-1}$. Residue applied in 1978 and 1979 was based on the amount of crop residue produced on each plot and that produced on the $50 \%$ treatment. The resulting residue application rates approximated the $0,50,100$, and $150 \%$ treatment definitions. After grain harvest all crop residues were removed from the $0 \%$ treatment. The $50 \%$ treatment had $50 \%$ of the produced residue removed. The residue removed from the $50 \%$ treatment was added to the residue produced by the $150 \%$ treatment to account for the total residue application. Residue produced on the $100 \%$ treatment was returned after determining residue yield with no adjustments. In all cases, all residue was chopped and uniformly scattered over the entire plot surface by hand. Because of variation in residue production, the average application rate for the $0,50,100$, and $150 \%$ treatments was $0,57,100,167 \% ; 0,52,100$, and 154\%; and $0,61,100$, and $168 \%$ for corn, sorghum, and soybean, respectively.

Crops were planted with a Buffalo ${ }^{3}$ no-till planter in 0.51 $\mathrm{m}$ and $0.76-\mathrm{m}$ rows in 1978 and 1979 , respectively. In 1980 , all crops were planted using a John Deere Max-Emerge planter with $0.76-\mathrm{m}$ rows. No supplemental tillage operations were performed, and weeds were controlled using preemergence and postemergence herbicides at recommended rates for this area. We used no tillage because of the importance of surface-residue management on success of this system. In 1978 and $1979, \mathrm{NH}_{4} \mathrm{NO}_{3}$ was surface broadcast before planting on corn and sorghum plots at $70 \mathrm{~kg} \mathrm{~N} \mathrm{ha}^{-1}$. No fertilizer $N$ was applied to soybean during 1978 and 1979. In 1980, however, $45 \mathrm{~kg} \mathrm{~N} \mathrm{ha}^{-1}$ of $\mathrm{NH}_{4} \mathrm{NO}_{3}-\mathrm{N}$ was applied to all three crops.

Mid-summer plant populations were determined from plant counts in a minimum of $15.2 \mathrm{~m}$ of row. With variable stands, up to $72 \mathrm{~m}$ of row (six crop rows $12 \mathrm{~m}$ in length) were counted. Crop grain yield was measured after physiological maturity by harvesting $11.6 \mathrm{~m}$ from eight rows in each plot. Final grain yields were adjusted to $15.5,14$, and $13 \%$ water content, respectively, for corn, sorghum, and soybean. Residue yields were determined immediately after grain harvest by collecting and weighing all downed and standing residue from each plot. Standing residue was cut at $60 \mathrm{~mm}$. Final residue weights were corrected to an oven-dried basis.

Soil samples for soil water content, particle size analysis, organic matter, and $\mathrm{N}$ and $\mathrm{P}$ contents, were taken to a depth of $1.8 \mathrm{~m}$ on 8 May 1980 . Two $42-\mathrm{mm}$ diameter cores from each plot were composited at depth intervals of $0.3 \mathrm{~m}$, air dried overnight, and passed through a $2-\mathrm{mm}$ sieve. The abovementioned analyses were made by standard methods of the Univ. of Nebraska Soil Testing Laboratory. During the 1980 growing season, volumetric soil water contents were determined at one sample site within each experimental unit for corn and soybean to a depth of $1.6 \mathrm{~m}$ on 2-week intervals with a Troxler neutron soil moisture meter. Soil water retention curves were determined using distrubed soil samples and pressure plate desorption as described by Richards (1965). Soil temperatures under corn and soybean were measured throughout the 1980 growing season at the soil surface (under surface residue) and at a depth of $50 \mathrm{~mm}$. Thermocouple readings (Culik et al., 1982) were made at 6-h intervals from March through May, and at 2-h intervals from

\footnotetext{
${ }^{3}$ Mention of companies or commercial products does not imply recommendation or endorsement by the USDA or the Univ. of Nebraska-Lincoln over others not mentioned.
} 
Table 1-Grain yields of corn, sorghum, and soybean as related to percent of previous crop residue applied to soil surface.

\begin{tabular}{|c|c|c|c|c|}
\hline \multirow{2}{*}{$\begin{array}{l}\text { Residue } \\
\text { treatment }\end{array}$} & \multicolumn{4}{|c|}{ Grain yield } \\
\hline & 1978 & 1979 & 1980 & 3-yr avg \\
\hline \multirow[t]{2}{*}{$\%$} & \multicolumn{4}{|c|}{$-\mathrm{Mg} \mathrm{ha}^{-1}-$} \\
\hline & \multicolumn{3}{|c|}{ Corn } & \\
\hline $\begin{array}{r}0 \\
50 \\
100 \\
150\end{array}$ & $\begin{array}{l}3.8 \mathrm{a}^{*} \\
3.6 \mathrm{a} \\
4.7 \mathrm{a} \\
4.5 \mathrm{a}\end{array}$ & $\begin{array}{c}5.6 \mathrm{~b} \\
6.6 \mathrm{a} \\
6.4 \mathrm{a} \\
6.3 \mathrm{a}\end{array}$ & $\begin{array}{l}0.1 \mathrm{c} \\
0.2 \mathrm{bc} \\
0.4 \mathrm{~b} \\
1.0 \mathrm{a}\end{array}$ & $\begin{array}{l}3.1 b \\
3.4 a b \\
3.9 a \\
3.9 a\end{array}$ \\
\hline 150 & \multicolumn{3}{|c|}{ Sorghum } & \\
\hline $\begin{array}{r}0 \\
50 \\
100 \\
150\end{array}$ & $\begin{array}{l}2.5 \mathrm{~b} \\
3.6 \mathrm{a} \\
3.9 \mathrm{a} \\
4.0 \mathrm{a}\end{array}$ & $\begin{array}{l}3.8 \mathrm{a} \\
4.0 \mathrm{a} \\
3.3 \mathrm{a} \\
3.2 \mathrm{a}\end{array}$ & $\begin{array}{l}1.6 \mathrm{a} \\
1.6 \mathrm{a} \\
1.0 \mathrm{a} \\
1.3 \mathrm{a}\end{array}$ & $\begin{array}{l}2.7 \mathrm{a} \\
3.1 \mathrm{a} \\
2.7 \mathrm{a} \\
2.8 \mathrm{a}\end{array}$ \\
\hline \multicolumn{5}{|c|}{ Soybean } \\
\hline 0 & $1.6 \mathrm{a}$ & $1.0 \mathrm{~b}$ & $1.3 \mathrm{~b}$ & $1.3 \mathrm{~b}$ \\
\hline 50 & $1.4 a$ & $1.6 a$ & $2.1 \mathrm{a}$ & $1.7 \mathrm{a}$ \\
\hline 100 & $1.4 \mathrm{a}$ & $1.5 \mathrm{a}$ & $2.2 \mathrm{a}$ & $1.7 \mathrm{a}$ \\
\hline 150 & $1.3 a$ & $1.7 \mathrm{a}$ & $2.5 \mathrm{a}$ & $1.8 \mathrm{a}$ \\
\hline
\end{tabular}

* Means within crop type followed by the same letter are not significantly different at $p<0.05$ by Duncan's multiple range test.

June through October using a Campbell Scientific CR-5 data logger. The $50-\mathrm{mm}$ readings were an average of triplicate readings for each treatment, while the surface soil measurements were triplicate readings within one replicate of each crop.

Statistical analysis consisted of first subjecting data to analysis of variance, then using Duncan's multiple range test to separate means if differences were significant according to analysis of variance. Differences determined not to be significant are noted by being followed by the same letter in Tables 1 through 4.

\section{RESULTS AND DISCUSSION}

Crop grain yields for 1978 through 1980 are given in Table 1. In 1978, sorghum yields with no residue were 31 to $38 \%$ lower than those with residues, while yields of corn and soybean were not significantly affected by residue treatment. In 1979 and 1980, yields of corn and soybean for the $0 \%$ residue treatment were 13 and 75 , and 33 and $41 \%$ lower, respectively, than

Table 3-Plant populations of corn, sorghum, and soybean as related to percent of previous crop residue applied to soil surface.

\begin{tabular}{|c|c|c|c|c|}
\hline \multirow{2}{*}{$\begin{array}{l}\text { Residue } \\
\text { treatment }\end{array}$} & \multicolumn{4}{|c|}{ Plant population } \\
\hline & 1978 & 1979 & 1980 & 3-yr avg \\
\hline \multirow[t]{2}{*}{$\%$} & \multirow{2}{*}{\multicolumn{3}{|c|}{$\begin{array}{l}\text { Plants } \mathrm{m}^{-2}- \\
\text { Corn }\end{array}$}} & \\
\hline & & & & \\
\hline 0 & $2.7 a^{*}$ & $3.3 \mathrm{a}$ & $5.0 \mathrm{a}$ & $3.7 \mathrm{a}$ \\
\hline 50 & $2.3 a$ & $3.1 \mathrm{a}$ & $5.1 \mathrm{a}$ & $3.5 \mathrm{a}$ \\
\hline 100 & $2.6 \mathbf{a}$ & $3.2 \mathrm{a}$ & $5.1 \mathrm{a}$ & $3.6 \mathrm{a}$ \\
\hline \multirow[t]{2}{*}{150} & $2.6 \mathrm{a}$ & $3.3 \mathrm{a}$ & $4.9 \mathrm{a}$ & $3.6 \mathrm{a}$ \\
\hline & \multicolumn{3}{|c|}{ Sorghum } & \\
\hline 0 & $8.2 \mathrm{ab}$ & $11.5 \mathrm{a}$ & $7.3 a$ & $9.0 \mathrm{a}$ \\
\hline 50 & $9.1 \mathrm{a}$ & $10.4 \mathrm{ab}$ & $6.5 a b$ & $8.7 a$ \\
\hline 100 & $7.5 \mathrm{~b}$ & $8.7 \mathrm{~b}$ & $6.0 \mathrm{ab}$ & 7.4ab \\
\hline \multirow{2}{*}{150} & $5.9 \mathrm{c}$ & $9.2 \mathrm{~b}$ & $4.7 \mathrm{~b}$ & $6.6 \mathrm{~b}$ \\
\hline & \multicolumn{3}{|c|}{ Soybean } & \\
\hline 0 & $13.9 \mathrm{ab}$ & $15.6 \mathrm{a}$ & $20.9 a$ & $16.8 \mathrm{a}$ \\
\hline 50 & $14.4 \mathrm{a}$ & $16.4 a$ & $20.1 \mathrm{a}$ & $17.0 \mathrm{a}$ \\
\hline 100 & $12.5 \mathrm{ab}$ & $16.9 \mathrm{a}$ & $20.6 a$ & $16.7 \mathrm{a}$ \\
\hline 150 & $11.3 \mathrm{~b}$ & $17.2 \mathrm{a}$ & $18.1 \mathrm{~b}$ & $15.5 b$ \\
\hline
\end{tabular}

* Means within crop type followed by the same letter are not significantly different at $p<0.05$ by Duncan's multiple range test.
Table 2-Residue yields of corn, sorghum, and soybean as related to percent of previous crop residue applied to soil surface.

\begin{tabular}{|c|c|c|c|c|}
\hline \multirow{2}{*}{$\begin{array}{l}\text { Residue } \\
\text { treatment }\end{array}$} & \multicolumn{4}{|c|}{ Residue yield } \\
\hline & 1978 & 1979 & 1980 & 3-yr avg \\
\hline \multirow[t]{2}{*}{$\%$} & \multicolumn{4}{|c|}{$\longrightarrow \mathrm{Mg} \mathrm{ha}^{-1} \longrightarrow$} \\
\hline & \multicolumn{3}{|c|}{ Corn } & \\
\hline $\begin{array}{r}0 \\
50 \\
100 \\
150\end{array}$ & $\begin{array}{l}3.7 a^{*} \\
3.4 a \\
3.5 a \\
3.7 a\end{array}$ & $\begin{array}{c}6.7 \mathrm{a} \\
7.3 \mathrm{a} \\
7.1 \mathrm{a} \\
7.0 \mathrm{a}\end{array}$ & $\begin{array}{l}3.3 \mathrm{c} \\
4.7 \mathrm{~b} \\
5.0 \mathrm{~b} \\
6.2 \mathrm{a}\end{array}$ & $\begin{array}{l}4.6 \mathrm{~b} \\
5.1 \mathrm{ab} \\
5.2 \mathrm{a} \\
5.6 \mathrm{a}\end{array}$ \\
\hline \multicolumn{5}{|c|}{ Sorghum } \\
\hline $\begin{array}{r}0 \\
50 \\
100 \\
150\end{array}$ & $\begin{array}{l}4.2 \mathrm{ab} \\
4.6 \mathrm{a} \\
3.8 \mathrm{~b} \\
3.0 \mathrm{c}\end{array}$ & $\begin{array}{l}5.1 \mathrm{a} \\
6.1 \mathrm{a} \\
4.9 \mathrm{a} \\
5.0 \mathrm{a}\end{array}$ & $\begin{array}{l}3.0 \mathrm{a} \\
2.6 \mathrm{a} \\
2.8 \mathrm{a} \\
2.3 \mathrm{a}\end{array}$ & $\begin{array}{l}4.1 \mathrm{a} \\
4.4 \mathrm{a} \\
3.9 \mathrm{ab} \\
3.4 \mathrm{~b}\end{array}$ \\
\hline \multicolumn{5}{|c|}{ Soybean } \\
\hline $\begin{array}{r}0 \\
50 \\
100 \\
150\end{array}$ & $\begin{array}{l}3.2 \mathrm{ab} \\
3.3 \mathrm{a} \\
2.8 \mathrm{ab} \\
2.5 \mathrm{~b}\end{array}$ & $\begin{array}{l}3.9 \mathrm{~b} \\
5.4 \mathrm{a} \\
5.4 \mathrm{a} \\
5.9 \mathrm{a}\end{array}$ & $\begin{array}{l}2.6 \mathrm{c} \\
4.0 \mathrm{~b} \\
4.4 \mathrm{ab} \\
5.0 \mathrm{a}\end{array}$ & $\begin{array}{l}3.2 b \\
4.2 a \\
4.2 a \\
4.5 a\end{array}$ \\
\hline
\end{tabular}

* Means within crop type followed by the same letter are not significantly different at $p<0.05$ by Duncan's multiple range test.

for the $100 \%$ residue treatment. Yields of sorghum were not significantly affected by residue treatments. Generally, the removal or addition of $50 \%$ crop residues had little influence on grain yields. Average 3-yr grain yields for corn and soybean where crop residues were completely removed averaged 21 and $24 \%$ lower, respectively, than where all residues were left on the soil. There was no significant difference in 3-yr grain yields among residue treatments for sorghum.

Removal of crop residues had less effect on residue yield than grain yield. Average 3-yr corn and soybean residue yields where residues were completely removed were 12 and $24 \%$ lower than for the $100 \%$ residue treatment (Table 2). Reduced crop residue production by sorghum for the $150 \%$ residue rate was related to lower plant populations with greater rates of residues (Table 3). Sorghum is the smallest seeded of the three crops, and we experienced more difficulty

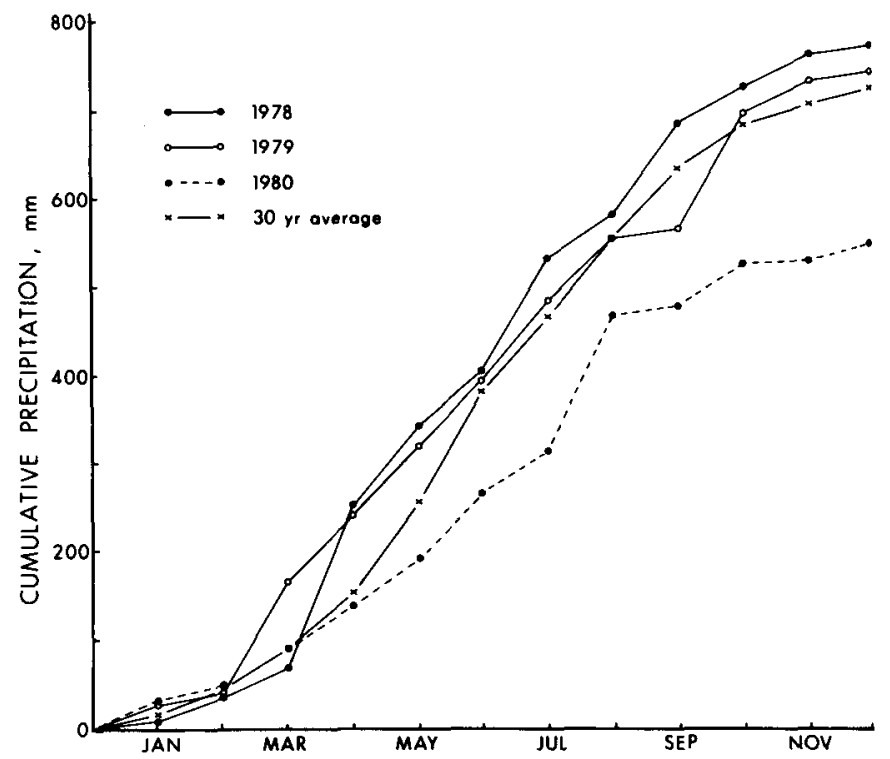

Fig. 1-Cumulative monthly precipitation for the years 1978 through 1980 and the 30-yr average for Lincoln, Nebr. 
with plant establishment under no tillage for this crop at the 100 and $150 \%$ residue rates.

Grain and crop residue production, as well as relative comparisons among treatments, were significantly influenced by climatic conditions each year. Precipitation during 1978 and 1979 (Fig. 1) was adequate for average to excellent crop production. The 1980 season, however, was very stressful for crop development. Only $122 \mathrm{~mm}$ of rain fell during June and July, $91 \mathrm{~mm}$ below normal for this period. Maximum air temperatures during July exceeded $41^{\circ} \mathrm{C}$ on 15 of 31 days. Corn was tasseling and silking at this time, and final grain yields were dramatically reduced as a result of physiological stress imposed by these conditions. Compared to grain production, corn residue yields were less seriously influenced because much of the aboveground biomass was produced before the stress period occurred. Grain yields of soybean and sorghum, compared to corn grain, were less seriously influenced by stress during 1980 because reproductive development of these crops occurred after timely rain and cooler temperatures arrived in early August.

Retention of surface crop residues apparently protected crop plants from physiological stress because, where residues were completely removed, corn and soybean grain and residue yields were significantly reduced. This is demonstrated by the fact that soil water storage was greater where residues were retained than where they were removed (Fig. 2). In May 1980, available water content in the soil profile to $1.8 \mathrm{~m}$ was greatest for the 100 and $150 \%$ residue treatments, intermediate for the 50\% treatment, and least for the $0 \%$ treatment. This effect was most pronounced in the 0.6to $1.5-\mathrm{m}$ depths in fields being planted to corn and soybean. Only $5 \mathrm{~mm}$ of available water was present at the 0.9- to 1.2-m depth. As shown in Table 4, these differences persisted for fields planted to corn and soybean until August, when precipitation occurred.

Surface mulches most effectively reduce evaporative loss during first-stage drying when the soil is wet and water loss rates are constant (Lemon, 1956). Consequently, surface crop residues most effectively reduce evaporative losses of soil water during periods of frequent rainfall and are less effective when the surface soil is dry for prolonged periods (Bond and Willis, 1969; Russel, 1939). Therefore, in the eastern Great Plains area, conservation of soil water by surface crop residues is greatest in the fall and spring, when crop plants are not extracting water. Between 1 Oct. 1979 and 7 May 1980, precipitation was fairly frequent and totaled $313 \mathrm{~mm}$. Total amount of available water to $1.8 \mathrm{~m}$ on 8 May 1980 averaged $164,202,232$, and 233 $\mathrm{mm}$ for the $0,50,100$, and $150 \%$ residue treatments, respectively. If we assume that soil water contents among residue treatments were similar at harvest in 1979 , the measured increases in water storage with surface residues would indicate 26,46 , and $46 \%$ less evaporation occurred on plots receiving 50,100, and $150 \%$ residue treatments, respectively, compared with no surface residues. Average rates of residue applied to all crops in October 1979 were $0,2.7,5.0$, and 7.8 $\mathrm{Mg} \mathrm{ha}^{-1}$ for the $0,50,100$, and $150 \%$ treatments, respectively. These results compare favorably with those of Greb (1966), who found that $1.1,2.2$, and $3.4 \mathrm{Mg}$

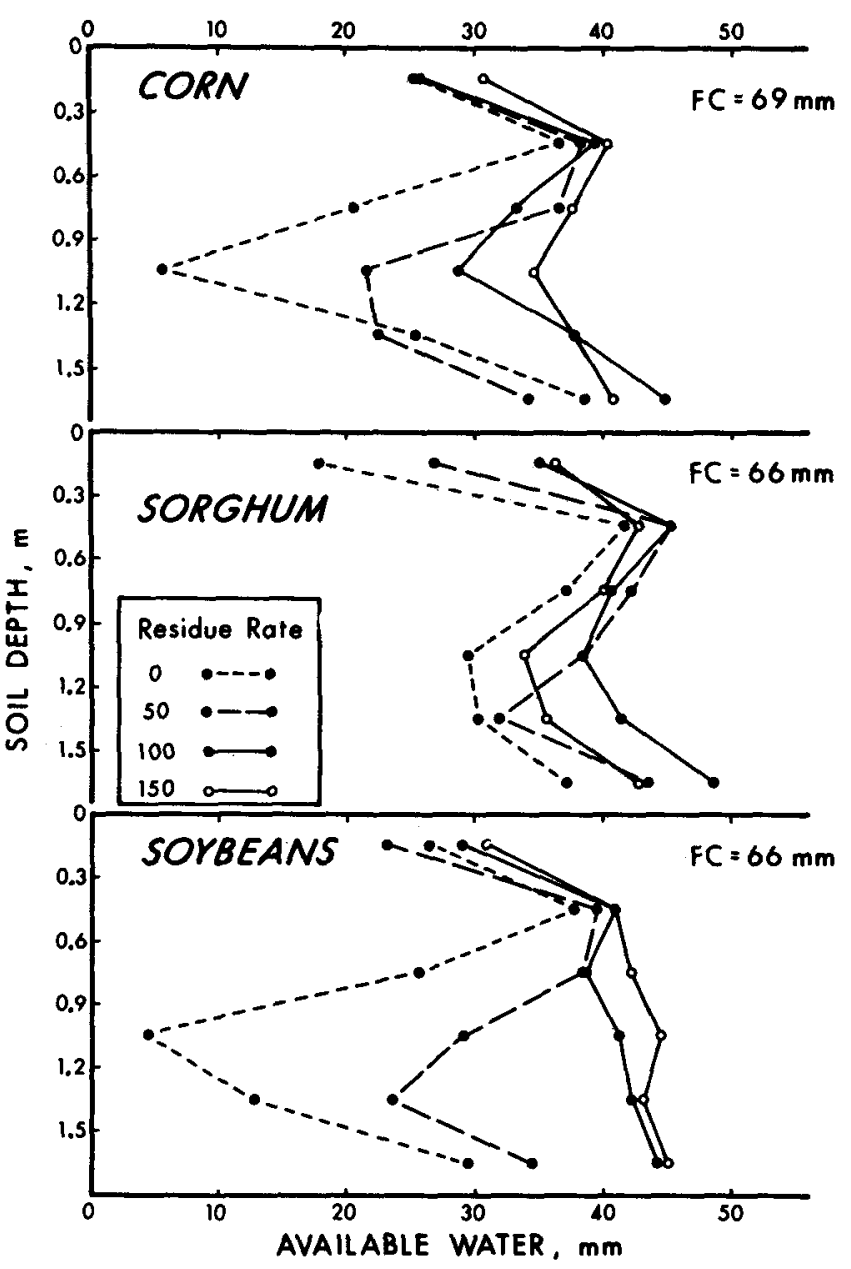

Fig. 2-Available soil water $\left(\mathrm{mm}\right.$ of $\mathrm{H}_{2} \mathrm{O}-\mathrm{mm}$ of $\mathrm{H}_{2} \mathrm{O}$ at 1.50 MPa matric suction) at $0.3-\mathrm{m}$ increments to a depth of $1.8 \mathrm{~m}$ on 8 May 1980, as influenced by residue rates for each crop to be planted. $\mathrm{FC}=$ average $\mathrm{mm}$ available water at field capacity for 0.3-m segments.

$\mathrm{ha}^{-1}$ surface wheat straw reduced evaporative losses by 16,33 , and $49 \%$, respectively, compared to bare soil. Lack of additional storage with the highest residue rate $\left(7.8 \mathrm{Mg} \mathrm{ha}{ }^{-1}\right)$, which achieved 90 to $100 \%$ surface cover, is also consistent with the report by Greb (1966) that straw application rates above $3.4 \mathrm{Mg}$ $\mathrm{ha}^{-1}$ ( $90 \%$ surface cover) had little influence on further

Table 4-Total available water to $1.8 \mathrm{~m}$ with different residue rates for corn and soybean in 1980 . $\dagger$

\begin{tabular}{|c|c|c|c|c|}
\hline \multirow[b]{2}{*}{ Crop } & \multirow{2}{*}{$\begin{array}{c}\text { Residue } \\
\text { treatment }\end{array}$} & \multicolumn{3}{|c|}{ Total available water } \\
\hline & & 26 June & 31 July & 25 Aug. \\
\hline & $\%$ & & $-\mathbf{m m}$ & \\
\hline Corn & $\begin{array}{r}0 \\
50 \\
100 \\
150\end{array}$ & $\begin{array}{l}110 c^{*} \\
162 b \\
227 a \\
219 a\end{array}$ & $\begin{array}{c}56 \mathrm{~b} \\
88 \mathrm{ab} \\
138 \mathrm{a} \\
102 \mathrm{ab}\end{array}$ & $\begin{array}{l}128 \mathrm{a} \\
172 \mathrm{a} \\
175 \mathrm{a} \\
178 \mathrm{a}\end{array}$ \\
\hline Soybean & $\begin{array}{r}0 \\
50 \\
100 \\
150\end{array}$ & $\begin{array}{l}156 \mathrm{c} \\
208 \mathrm{~b} \\
250 \mathrm{a} \\
243 \mathrm{ab}\end{array}$ & $\begin{array}{l}95 \mathrm{c} \\
108 \mathrm{bc} \\
142 \mathrm{ab} \\
163 \mathrm{a}\end{array}$ & $\begin{array}{l}129 b \\
144 a b \\
177 a b \\
189 a\end{array}$ \\
\hline
\end{tabular}

* Means followed by the same letter are not significantly different at $p$ $<0.05$ by Duncan's multiple range test.

† Total available water $=\mathbf{m m}$ of water measured $-\mathbf{m m}$ of water at permanent wilting point $(-1.50 \mathrm{MPa})$. 


\begin{tabular}{|c|c|c|c|c|c|c|c|c|}
\hline \multirow{2}{*}{$\begin{array}{l}\text { Residue } \\
\text { treatment, \% }\end{array}$} & \multicolumn{8}{|c|}{ Soil temperatures, ${ }^{\circ} \mathrm{C}$} \\
\hline & Mar. & Apr. & May & June & July & Aug. & Sept. & Oct. \\
\hline & \multicolumn{8}{|c|}{ Mean } \\
\hline 0 & 2.4 & 10.6 & 18.2 & 25.4 & 27.8 & 25.0 & 20.4 & 11.6 \\
\hline 50 & 2.2 & 10.4 & 17.8 & 25.0 & 27.2 & 24.4 & 19.4 & 11.2 \\
\hline 100 & 2.1 & 10.2 & 17.4 & 24.7 & 26.9 & 24.2 & 19.2 & 11.4 \\
\hline \multirow[t]{2}{*}{150} & 1.9 & 9.5 & 17.0 & 24.2 & 26.4 & 23.8 & 18.6 & 11.0 \\
\hline & \multicolumn{8}{|c|}{ Average daily maximum } \\
\hline 0 & 4.6 & 15.2 & 22.6 & 30.6 & 32.4 & 28.8 & 25.1 & 15,8 \\
\hline 50 & 4.2 & 14.6 & 22.4 & 30.2 & 31.8 & 27.7 & 23.3 & $\begin{array}{l}15.2 \\
\text {. }\end{array}$ \\
\hline 100 & 3.8 & 14.0 & 21.5 & 29.8 & 30.9 & 27.2 & 22.6 & 14.6 \\
\hline 150 & 3.4 & 12.9 & 21.0 & 29.4 & 30.6 & 26.7 & 21.8 & 14.3 \\
\hline
\end{tabular}

reducing evaporative losses. Thus, an additional 34 $\mathrm{mm}$ of water was stored for each $2.5 \mathrm{Mg} \mathrm{ha}{ }^{-1}$ residue left on the soil surface up to $5.0 \mathrm{Mg} \mathrm{ha}{ }^{-1}$.

Differences in soil temperature in 1980 also influenced crop development and ultimate yield. Mean and maximum soil temperatures at $50 \mathrm{~mm}$ were highest with $0 \%$ residue and lowest with $150 \%$ residues (Table 5). For both corn and soybean, soil temperatures during March through October averaged 0.2 to $1.0^{\circ} \mathrm{C}$ cooler for each $50 \%$ crop residues left on the soil surface. Walker (1969) found that growth rate of corn seedlings declined dramatically as soil temperatures increased from 26 to $35^{\circ} \mathrm{C}$. Maximum soil surface temperatures during June through August were very high and in a range which undoubtedly influenced crop growth and ultimate yield (Table 6). In July and early August, surface temperatures in $0 \%$ residue treatments were 54.6 and 56.1 and 52.5 and $49.6^{\circ} \mathrm{C}$, respectively, for corn and soybeans. Surface temperatures for the 50,100 , and $150 \%$ residue treatments averaged over corn and soybean for the months of July and August were $4.2,8.6$, and $5.7^{\circ} \mathrm{C}$ cooler, respectively, than the $0 \%$ residue treatment. Thus, maximum soil temperatures in June through August were in a range that could reduce growth of corn.

Differences in surface soil temperatures were associated with differences in plant canopy development, as well as differences in soil water content. In midJuly, corn plants on the $0,50,100$, and $150 \%$ residue treatments averaged 1.2, 1.8, 2.0, and $2.1 \mathrm{~m}$ tall. Corn became severely wilted on the $0 \%$ residue treatment by this time and lost leaf area rapidly after mid-July. Corn on the $50 \%$ treatment was affected to a lesser extent, and full canopy closure occurred on the 100 and $150 \%$ treatments. For soybean, plant heights in mid-August for the $0,50,100$, and $150 \%$ treatments were $0.4,0.8,0.9$, and $0.9 \mathrm{~m}$, respectively, with canopy closure not occurring on the $0 \%$ treatment until early September. From data collected, it was not possible to determine if the higher soil temperatures caused reduced growth or if reduced growth was caused by reduced water availability, and these factors combined to produce higher soil temperatures.

Removal of crop residues will ultimately reduce levels of soil organic matter, $\mathrm{N}$ and $\mathrm{P}$, and effect changes in soil physical characteristics such as bulk density. In the relatively short term of our study ( $3 \mathrm{yr})$, however, there was no significant difference among residue treatments for these parameters in the surface $(0-75$ $\mathrm{mm}$ ) or to a depth of $1.8 \mathrm{~m}$.
Table 6-Maximum temperatures at the soil surface during 1980 with different residue rates.

\begin{tabular}{lcccc}
\hline & & \multicolumn{3}{c}{ Maximum temperature } \\
\cline { 3 - 5 } Crop & $\begin{array}{c}\text { Residue } \\
\text { treatment }\end{array}$ & June & July & August \\
\cline { 3 - 5 } Corn & $\%$ & & ${ }^{\circ} \mathrm{C}$ & \\
& 0 & 53.0 & 54.6 & 56.1 \\
& 50 & 51.5 & 47.5 & 51.1 \\
Soybean & 100 & 49.2 & 46.6 & 50.3 \\
& 150 & 47.0 & 43.6 & 49.2 \\
& 0 & 50.4 & 52.5 & 49.6 \\
& 50 & 48.2 & 49.9 & 47.4 \\
& 100 & 51.1 & 42.5 & 39.0 \\
& 150 & 50.5 & 49.5 & 47.6 \\
\hline
\end{tabular}

\section{CONCLUSIONS}

Complete removal of crop residues reduced grain and residue yields of no-till corn and soybeans by 21 to $24 \%$ and 12 to $24 \%$, respectively. Yields of no-till sorghum were unaffected by residue removed, probably because poor plant stands occurred with surface residues. Sorghum is also more tolerant of water and heat stress than corn or soybeans. Grain and residue yields were not significantly reduced where $50 \%$ crop residues were removed, compared to where $100 \%$ residues were retained. Stunted growth, physiological stress, and decreased yields of corn and soybeans where residues were completely removed resulted predominantly from lack of available soil water, poor canopy development, and excessively high surface soil temperatures. Surface crop residues reduced stress of crop plants during periods of drought and high air temperatures. Similar conclusions were reached by Lal $(1974,1976)$ and Lal et al. (1980) in West Africa, who found that yield increases of corn and cowpeas [Vigna unquiculata (L.) Walp.] resulting from application of $2 \mathrm{Mg} \mathrm{ha}^{-1}$ of rice straw mulch resulted predominantly from increased water storage and reduced maximum soil temperatures compared to bare soil. As in our study, excessively high soil temperatures on nonmulched soils during critical periods for corn silking in a stressful year dramatically reduced final grain yields.

Results of our study confirm the economical importance of crop residues in maintaining an optimum physical environment for crop plant growth. The indiscriminate removal of residues for use as alternate energy sources could have severe long-term consequences on soil productivity in stressful climates, in addition to the short-term consequences documented here. If soil erosion were also accelerated by crop residue removal, long-term effects would be even greater.

\section{ACKNOWLEDGMENTS}

The authors extend thanks to Martin Culik for his dedication in managerial and analytical aspects of this project. Appreciation is also expressed to Timothy Travis for his support of this project and assistance in programming for soil temperature measurements.

\section{REFERENCES}

1. Barber, S.A. 1979. Corn residue management and soil organic matter. Agron. J. 71:625-627.

2. Bond, J.J., and W.O. Willis. 1969. Soil water evaporation: surface residue rate and placement effects. Soil Sci. Soc. Am. Proc. 33:445-448.

3. Burwell, C.C. 1978. Solar biomass energy: An overview of U.S. 
potential. Science 199:1041-1048.

4. Culik, M.N., J.W. Doran, and K.A. Richards. 1982. Construction of soil thermocouples for the novice. Soil Sci. Soc. Am. J. 46:882-884.

5. Doran, J.W., and J.F. Power. 1983. The effects of tillage on the nitrogen cycle in corn and wheat production. p 441-445. In $\mathrm{R}$. Lowrance et al. (ed.) Nutrient cycling in agricultural ecosystems. Univ. of Georgia Coll. Agric. Spec. Publ. no. 23. Athens, $\mathrm{Ga}$.

6. Greb, B.W. 1966. Effects of surface-applied wheat straw on soil water losses by solar distillation. Soil Sci. Soc. Am. Proc. 30:786788 .

7. Greenland, D.J. 1975. Bringing the green revolution to the shifting cultivator. Science 190:841-844.

8. Lal, R. 1976. Soil erosion problems on an Alfisol in western Nigeria and their control. Int. Inst. Trop. Agric. Monograph No. 1. IITA, Ibadan, Nigeria.

9. Lal, R. 1974. Soil temperature, soil moisture and maize yield from mulched and unmulched tropical soils. Plant Soil 40:129_ 143.

10. Lal, R., D. DeVleeschauwer, and R. Malafa. 1980. Changes in properties of a newly cleared tropical Alfisol as affected by mulching. Soil Sci. Soc. Am. J. 44:827-833.

11. Larson, W.E., C.E. Clapp, W.H. Pierre, and Y.B. Morachan. 1972. Effects of increasing amounts of organic residues on continuous corn: Organic carbon, nitrogen, phosphorus, and sulfur. Agron. J. 64:204-208.

12. Larson, W.E., R.F. Holt, and C.W. Carlson, 1978. Residues for soil conservation. p. 1-15. In W.R Oschwald (ed.) Crop residue management systems. Am. Soc. of Agron. Spec. Publ. no. 31. Madison, Wis.

13. Lemon, E.R. 1956. The potentialities for decreasing soil moisture evaporation loss. Soil Sci. Soc. Am. Proc. 20:120-125.

14. Linstrom, M.J., S.C. Gupta, C.A. Onstad, R.F. Holt, and W.E.
Larson. 1981. Crop residue removal and tillage: Effects on soil erosion and nutrient loss in the corn belt. USDA-ARS Agric. Inf. Bull. no. 442. U.S. Government Printing Office. Washington, D.C

15. Linstrom M.J., E.L. Skidmore, S.C. Gupta, and C.A. Onstad. 1979. Soil conservation limitations on removal of crop residues for energy production. J. Environ. Qual. 8:533-537.

16. Mannering, J.V., and L.D. Meyer. 1963. The effects of various rates of surface mulch on infiltration and erosion. Soil Sci. Soc. Am. Proc. 27:84-86.

17. Office of Technology Assessment. 1980. Energy from biological processes. Rep. no. OTA-E-123. Washington, D.C.

18. Parr, J.F., and R.I. Papendick. 1978. Factors affecting the decomposition of crop residues by microorganisms. p. 101-129. In W.R. Oschwald (ed.) Crop residue management systems. Am. Soc. of Agron. Spec. Publ. no. 31. Madison, Wis.

19. Power, J.F., and J.O. Legg. 1978. Effect of crop residues on the soil chemical environment and nutrient availability. p. 85-100. In W.R. Oschwald (ed.) Crop residue management systems. Am. Soc. of Agron. Spec. Publ. no. 31. Madison, Wis.

20. Richards, L.A. 1965. Physical condition of water in soil. In C.A. Black (ed.) Methods of soil analysis (Part 1). Agronomy 9:128137. Am. Soc. of Agron., Madison, Wis.

21. Russel, J.C. 1939. The effects of surface cover on soil moisture losses by evaporation. Soil Sci. Soc. Am. Proc. 4:65-67.

22. United States Department of Agriculture. 1978. Report on improving soils with organic wastes. 1979-0-623 484/770. U.S. Govt. Printing Office, Washington, D.C.

23. Walker, J.M. 1969. One-degree increments in soil temperatures affect maize seedling behavior. Soil Sci. Soc. Am. Proc. 33:729 736.

24. Willis, W.O., C.W. Carlson, J. Alessi, and H.J. Haas. 1961. Depth of freezing and spring runoff as related to fall soil moisture level. Can. J. Soil Sci. 41:115-123. 